\title{
SÍDLISKO Z NESKOREJ DOBY BRONZOVEJ V DETVE V POLOHE LÚČNA ŠTVRTัT ${ }^{1}$
}

\author{
Noémi Beljak Pažinová - Ladislav Chmelo
}

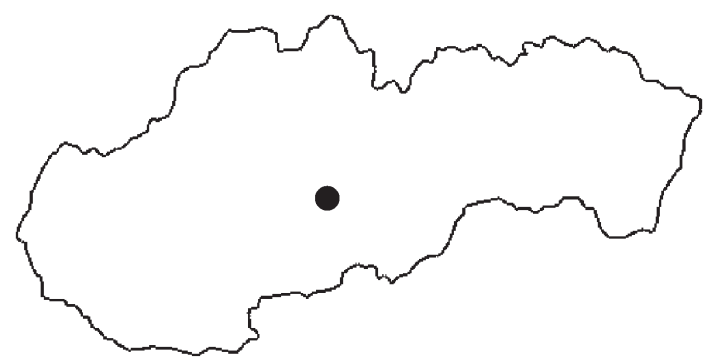

DOI: https://doi.org/10.31577/szausav.2019.65.3

Key words: Slovakia, Detva, Late Bronze Age, Urnfield cultures, rescue excavation, settlement finds

\section{The Settlement from the Late Bronze Age in Detva, Lúčna štvrt' (Meadow District) Site}

The aim of this article is to present results of the rescue excavation carried out in spring 2016 at the site of Lúčna štvrt’ in Detva, where settlement from the end of the Bronze Age had been discovered. The article presents finds discovered during the removal of the topsoil and monitoring of excavated foundations of a detached house at building plot no. $7381 / 27$ in the residential area of Detva. In the corner of the building plot with area of approx. $10 \mathrm{~m}^{2}$, a rich cultural layer and groundplan of a quadratic structure with an oven in the interior were uncovered. Dating of the settlement to the Late Bronze Age is enabled by fragments of various smaller and bigger mostly thick-walled vessels and pottery with high-quality black burnished surface including slanted as well as vertical flutings. It is a newly discovered settlement corresponding with the known prehistoric hillfort of Detva-Kalamárka, which is approx. $5 \mathrm{~km}$ north of the studied site.

\section{ÚVOD}

Katedra archeológie UKF $\mathrm{v}$ Nitre realizovala $\mathrm{v}$ časti Lúčna štvrt’ $\mathrm{v}$ centre Detvy záchranný archeologický výskum v polovici apríla 2016. Na predmetnej polohe sa postupne rozrastá nová štvrt’ rodinných domov vrátane napojenia na inžinierske siete a komunikácie.

Čast̉ Lúčna štvrt’ sa nachádza na pomedzí medzi starou historickou častou mesta a novým sídliskom mesta Detva. Lokalita je situovaná na svahu klesajúcim juhovýchodným smerom k Detvianskemu potoku. Vyššie položené časti polohy (390-405 m n. m.) doteraz slúžili ako lúky, pasienky, resp. na polnohospodárske účely, nižšie časti svahu (380-390 m n. m.) boli už v minulosti využité na výstavbu rodinných domov. Investičná výstavba novej zóny rodinných domov, ktorá v polohe začala v roku 2014, sa zameriava na zatial' stavebnou činnostou nedotknutú hornú plochu.

Záchranný výskum na parcele 7381/27, k. ú. Detva, realizovali autori článku a vyvolaný bol stavbou rodinného domu. Už počas sledovania terénnych úprav na ploche parcely sa podarilo identifikovat prvé nehnutelné archeologické objekty a bohatú materiálnu kultúru. Zámerom príspevku je predstavił objavené minulé osídlenie polohy, pričom okrem analýzy nálezovej situácie a vyhodnotenia spracovania archeologických nálezov je cielom skúmanú lokalitu zasadit do rámca osídlenia Detvianskej kotliny v neskorej dobe bronzovej.

\section{CHARAKTERISTIKA LOKALITY A PRIEBEH VÝSKUMU}

Lokalita v časti Lúčna štvrt’ (obr. 1) sa nachádza mimo historického intravilánu obce Detva, situovanej severne od polohy a na hranici s novou bytovou zástavbou mesta. Z geomorfologického hladiska

1 Práca vznikla v rámci grantového projektu VEGA 1/0208/17 „Z pontských stepí na západ - ku Karpatom a Dunaju“ a bola podporená Agentúrou na podporu výskumu a vývoja na základe zmluvy č. APVV-0063-17 Vita intra muros - interdisciplinárny výskum hradov stredného Slovenska. 
patrí toto územie do celku Zvolenská kotlina a podcelku Detvianska kotlina. Geologická stavba územia je tvorená v prevažnej miere neogénnymi vulkanitmi stratovulkánu Pol’ana a stratovulkánu Javorie. Územie mesta Detva spadá prevažne do povodia Hrona. Hlavnou riekou oblasti je Slatina, ktorá preteká východo-západným smerom južnou častou intravilánu mesta. Severnú čast' mesta odvodňuje najvýznamnejší tok pretekajúci $\mathrm{v}$ severojužnom smere Detvou a je známy ako Detviansky potok, ktorý je pravostranným prítokom rieky Slatina. Čast' Lúčna štvrt', na ktorej sa lokalita nachádza, je situovaná na pravej terase Detvianskeho potoka.

Skúmaná plocha pod novostavbou rodinného domu je súčastou novej výstavby nadväzujúcej na západný koniec ulice Lúčna štvrț. Pozemok určený na výstavbu rodinného domu na parc. 7381/27 sa nachádza na mierne klesajúcej terase juhovýchodným smerom $\mathrm{k}$ Detvianskemu potoku. Parcela mala pred úpravou charakter lúky, donedávna bola využívaná ako pol’nohospodárska pôda. Prevýšenie na mieste parcely z východu na západ dosahovalo asi 0,4 m, preto ako prvý krok v rámci zemných prác bola realizovaná skrývka ornice a úprava (vyrovnanie) terénu (obr. 2: 1). Hned’ po skrývke druhého pásu ornice na ploche $\mathrm{v}$ juhozápadnej časti parcely sa podarilo identifikovat prvé črepové nálezy a v pôdoryse sa
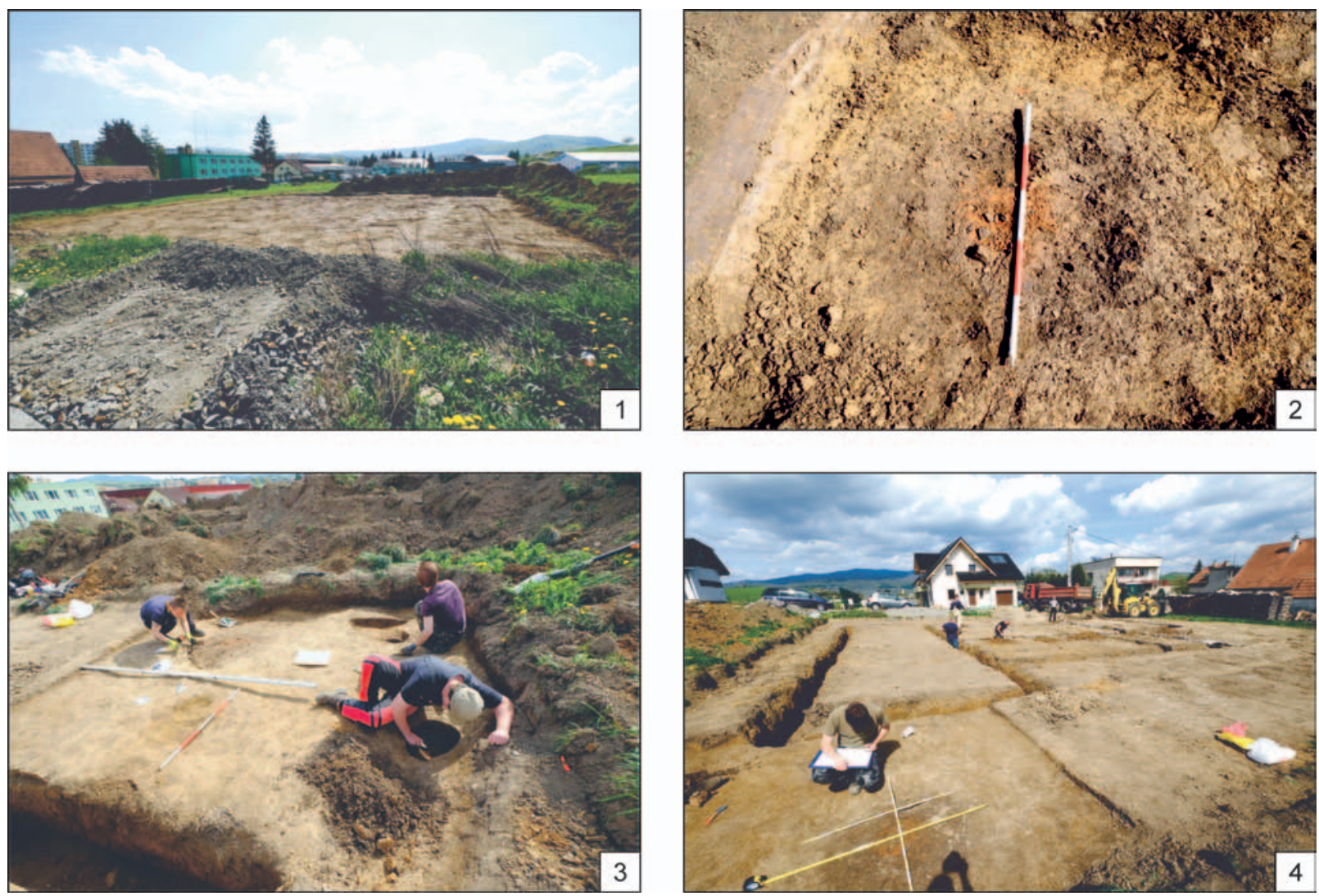

Obr. 2. Detva, Lúčna štvrt', parc. 7381/27. Dokumentácia priebehu výskumu. 


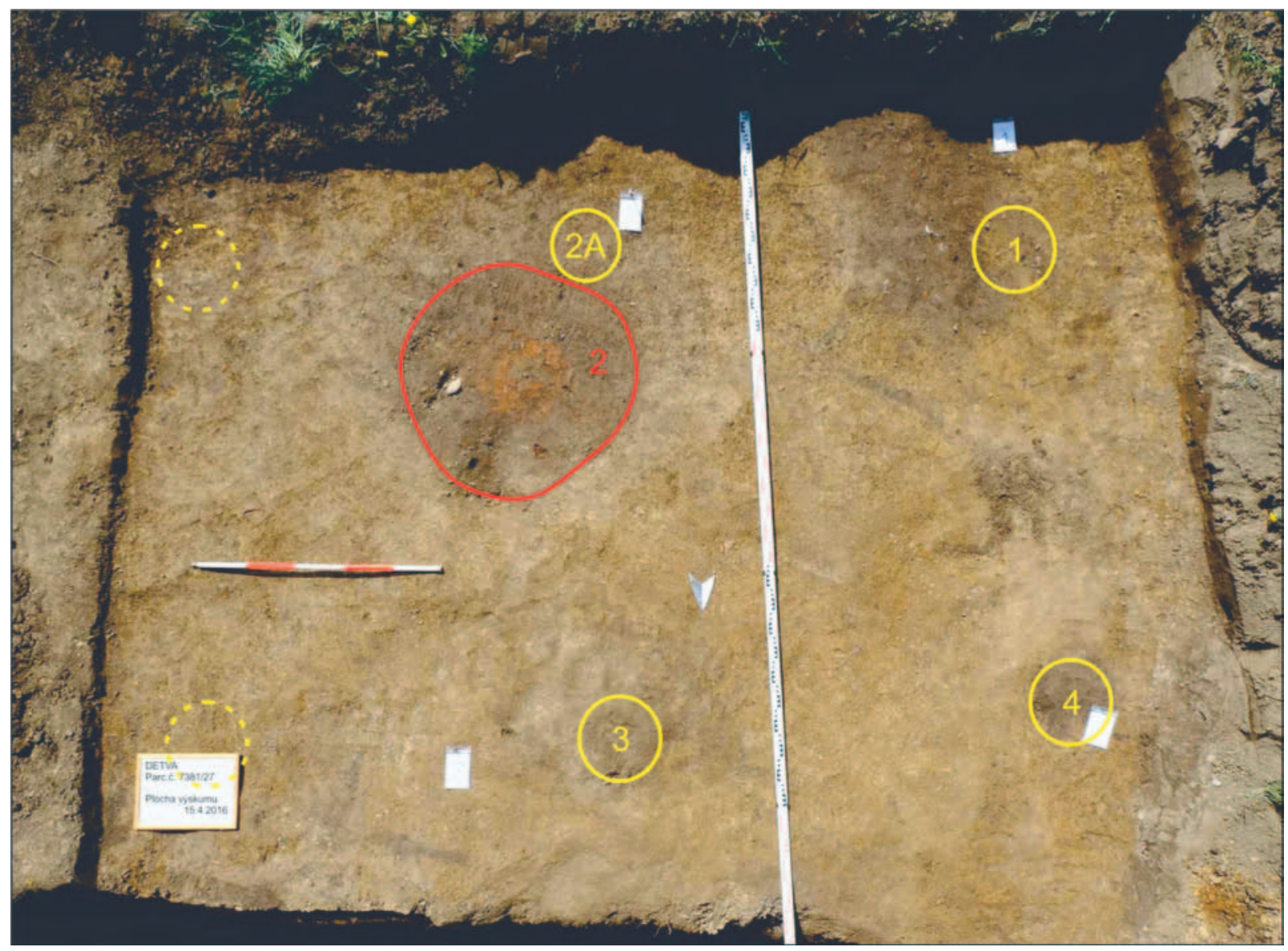

Obr. 3. Detva, Lúčna štvrt’, parc. 7381/27. Identifikované archeologické objekty na ploche výskumu. 1, 2A, 3, 4 - kolové jamy (žltá plná čiara); 2 - vykurovacie zariadenie (červená plná čiara); predpokladané d’alšie kolové jamy (prerušovaná žltá čiara).

črtajúci archeologický objekt (obr. 2: 2). V týchto miestach sa preto postupovalo plošným odkryvom (obr. 2: 3). Na ostatnej ploche sa po odobraní ornice a úpravách terénu neidentifikovali žiadne archeologické nálezy ani situácie. Nálezy neboli zaznamenané ani počas zemných prác výkopu základov rodinného domu nepravidelného kvadratického pôdorysu s maximálnymi rozmermi 18,85 x 14,10 m (obr. 2: 4). Stavba rodinného domu nebola podpivničená a híbka základových pásov dosahovala $0,8 \mathrm{~m}$. V profiloch výkopov základov sa zretel’ne rysovala vrchná sivočierna humusová vrstva (ornica/podorničie; mocnost’ 0,1-0,15 m) a pod ňou sa nachádzala vrstva tmavožltej hutnej ílovej hliny (podložie), ktorá siahala až po dno výkopu.

\section{Nálezová situácia}

Archeologické objekty a nálezy sa podarilo identifikovat’ v juhozápadnej časti plochy parcely 7381/27, k. ú. Detva. Manuálne začistenie plochy (obr. 3) ukázalo rozmiestnenie troch kolových jamiek (obj. 1, 3, 4) a jedného sídliskového objektu s výraznou vrstvou prepálenej hliny a uhlíkov (deštruované vykurovacie zariadenie), obj. 2. Ďalšia kolová jama (obj. 2A) sa črtala pri obvode piecky (?).

\section{Opis objektov}

\section{Objekt 1 (obr. 4)}

Zapustený bol do súvislého žltohnedého ílovitého podložia a jeho výplň tvorila tmavočierna hlina. Mal pravidelný kruhový pôdorys (pr. 0,3 m), ktorého steny sa smerom ku dnu pozvolna zužovali a prechádzali plynule do dna v max. hlbke 0,11 m. Profil jamy bol v tvare písmena „U“. Objekt bol odkrytý najprv na polovicu (južná čast) 

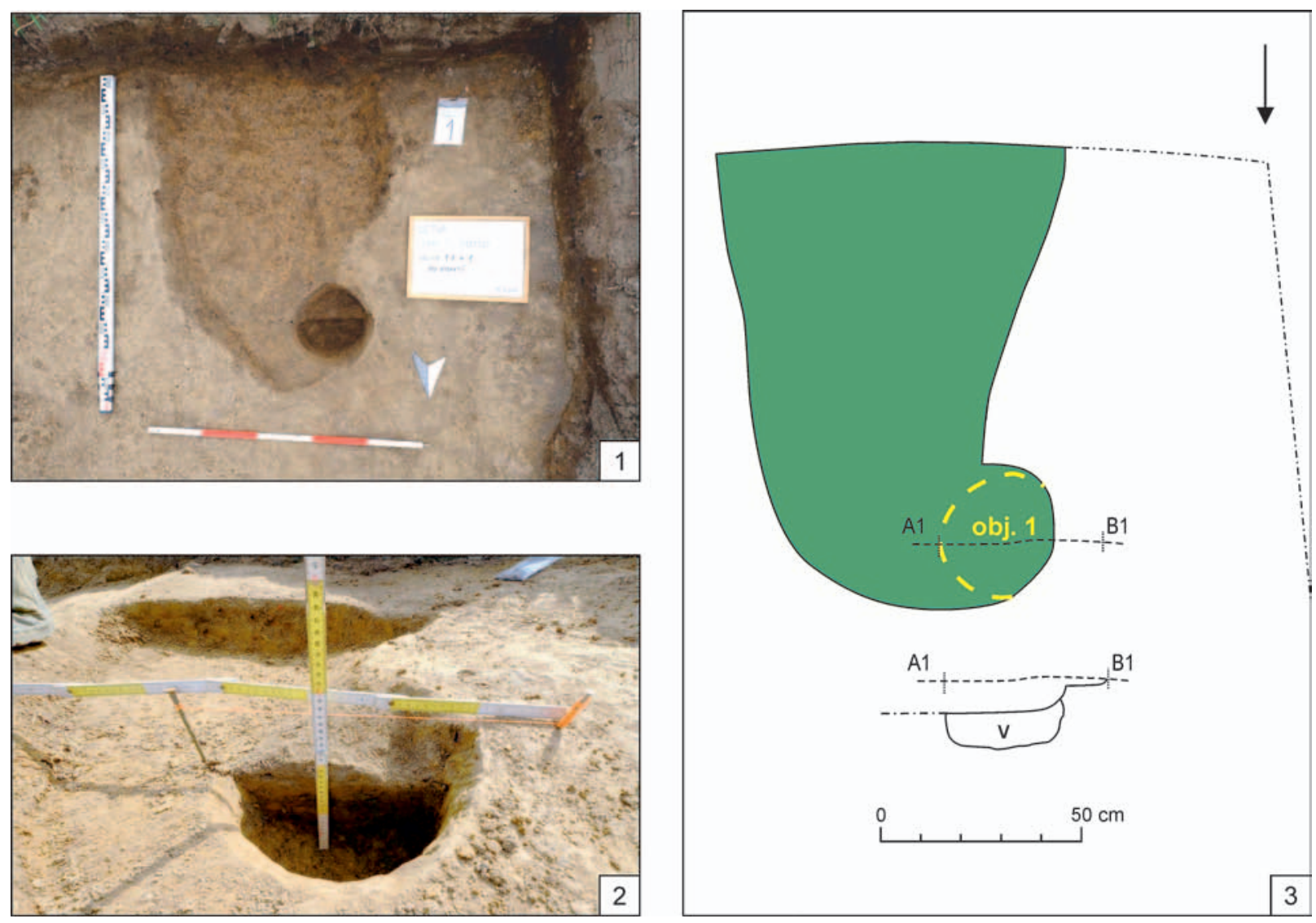

Obr. 4. Detva, Lúčna štvrt', parc. 7381/27. Fotografická (1, 2) a kresbová (3) dokumentácia kultúrnej vrstvy (zelená farba) a kolovej jamy obj. 1 (prerušovaná žltá čiara). Legenda: $\mathrm{V}$ - tmavočierna výplň objektu; bodkočiarkovaná čiara - hranica parcely.

a po dokumentácii bol vybraný celý až po podložie. Našiel sa na severozápadnom okraji od okolitého prostredia farebne odlísitel'nej kultúrnej vrstvy s nálezmi. Vrstva bola pomerne plytká $(0,03 \mathrm{~m})$ a zachovala sa v podorničí len v juhozápadom rohu skúmanej parcely.

Rozmery: dí. 0,3; š. 0,3; hí. 0,11 m.

Nálezy (z obj. 1 a kultúrnej vrstvy): 80 ks črepov (z toho 12 typických), 9 ks mazanice.

Poznámka: Pri začistovaní plochy nad objektom sa objavila aj sánka vel'kého prežúvavca (hovädzí dobytok) so zachovanou jednou stoličkou M 1. Nie je však isté, či ju môžeme priradit k nálezovému celku, nakol'ko sa nachádzala na pomedzí ornice a podložia. Tafonomicky ide o vel’mi zle zachovanú kost̉ jedinca starého okolo 30 a viac mesiacov. Výrazné poškodenie kostného tkaniva naznačuje vel’mi agresívnu pôdu (určila Mgr. K. Šimunková).

Interpretácia: kolová jama; súčast' pôdorysu stavby domu.

\section{Objekt 2 (obr. 5)}

Väčší objekt, ktorý mal tvar nepravidelného kruhového pôdorysu (pr. 1,0 m) so súvislou hutnou prepálenou mazanicou v strednej časti. Bol vyberaný na polovicu (najprv južná čast'), po kresbovej dokumentácii a fotodokumentácii bol dobratý až po žlté ílové podložie. Južný profil objektu má pravidelný lavórovitý tvar (písmeno „U“) s plynule klesajúcimi stenami k nerovnému dnu v híbke $0,54-0,56 \mathrm{~m}$. V profile bolo možné jasne sledovat’ deštrukciu mazanicovej konštrukcie (vrstva V1), ktorú obkolesovala tmavosivo-čierna výplň objektu (vrstva V2), nasledovaná sivou až sivobielou popolovou vrstvou (vrstva V3). Vo vrstve V2 sa objavilo aj väčšie množstvo andezitových kameňov. Na dne sa nachádzala sivočierna stlačená ílovitá vrstva (vrstva V4). Pri vyberaní okrajových častí objektu bola v jeho juhozápadnej časti objavená plytká kolová jama, obj. 2A.

Rozmery: dí. 1,56; š. 1,42; hí. 0,56 m.

Nálezy: 127 ks črepov (z toho 34 typických), fragment kamenného závažia, fragment kamennej podložky, 1 ks štiepanej industrie, 1 ks kamennej osličky, min. 72 ks mazanice, 13 ks andezitových kameňov.

Interpretácia: interiérová azda vykurovacia (?) piecka, ktorá mohla byt’ súčast’ou interiéru stavby, z ktorej sa podarilo zachytit’ min. štyri kolové jamy. 

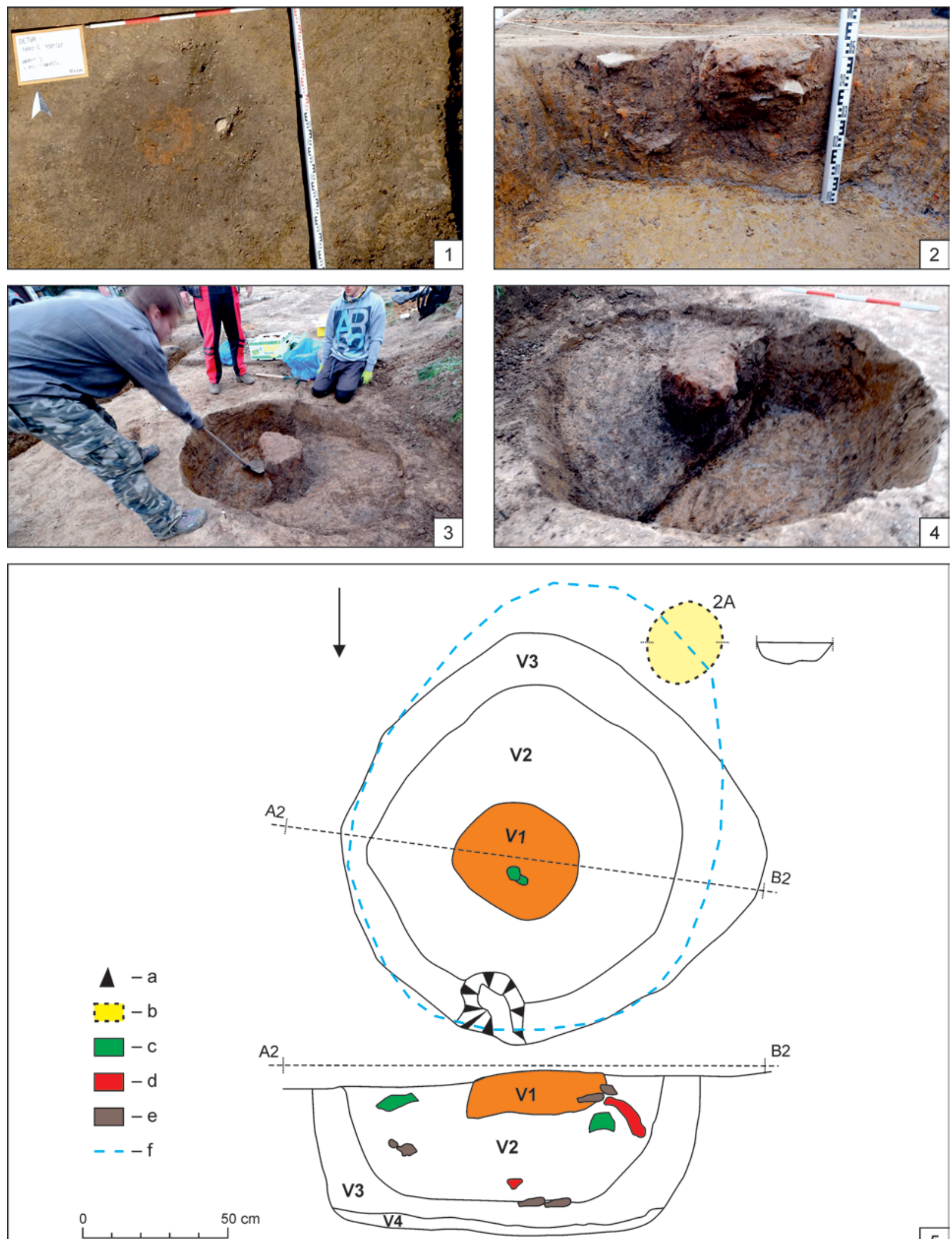

Obr. 5. Detva, Lúčna štvrt', parc. 7381/27, obj. 2.1 - pôdorys po začistení; 2 - južný profil; 3 - postupné vyberanie objektu; 4 - po vybraní južnej polovice objektu; 5 - dokumentácia vykurovacieho zariadenia (obj. 2) a kolovej jamy (obj. 2A). Legenda: V1 - súvislá sýtočervená mazanicová prepálená vrstva; V2 - tmavosivo-čierna výplň objektu; V3 - sivastá až sivobiela popolová vrstva; V4 - sivočierna stlačená ílovitá vrstva; a - ukotvenie JCB, porušená čast’ objektu; b - kolová jama (obj. 2A); c - keramika; d - mazanica; e - andezitové kamene; f - hranica objektu po výbere až po ílové podložie. 

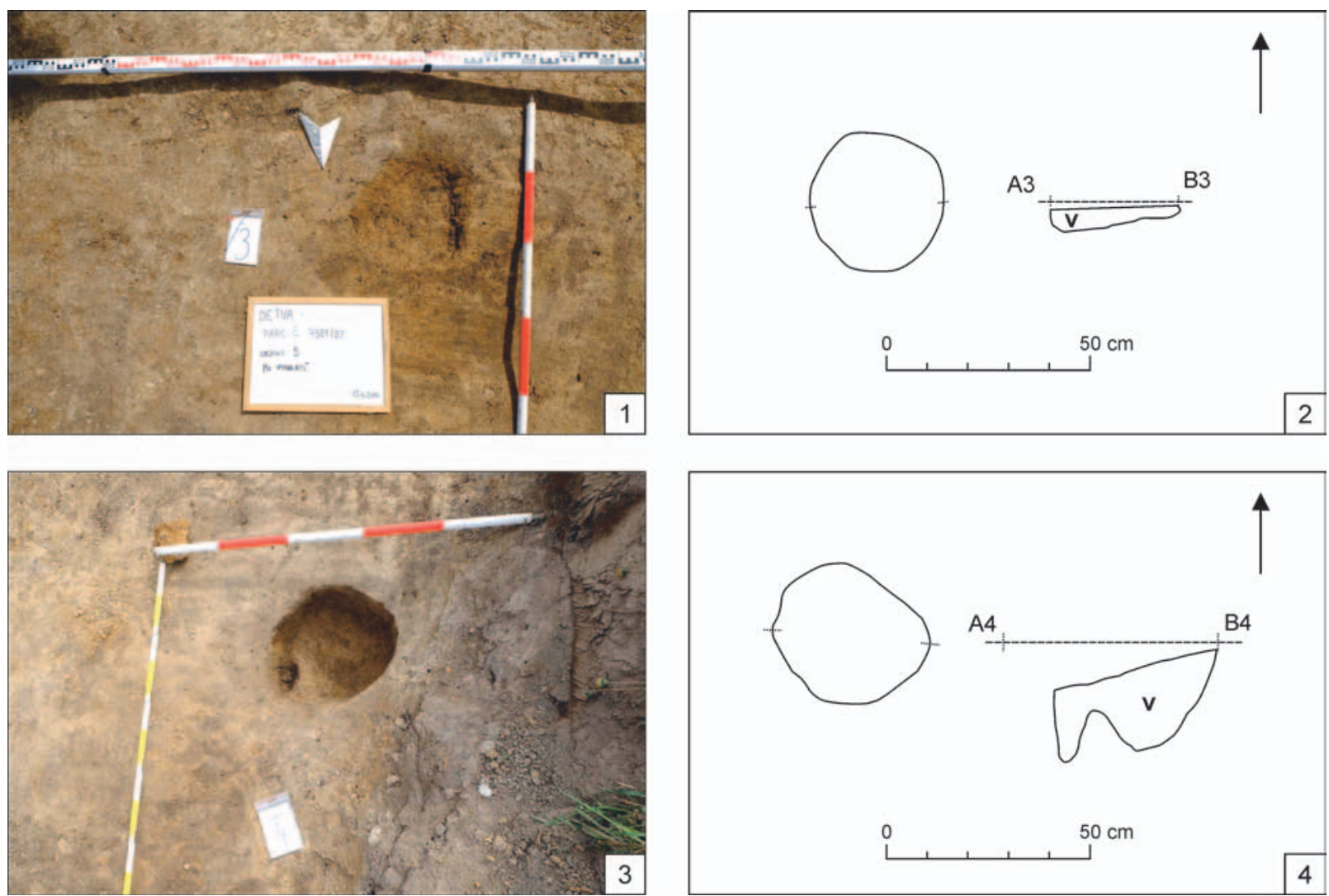

Obr. 6. Detva, Lúčna štvrt', parc. 7381/27. Dokumentácia kolových jám. 1, 2-obj. 3; 3, 4-obj. 4. Legenda: V - tmavohnedá výplň objektu.

\section{Objekt 2A (obr. 5: 5)}

Do žltohnedého podložia jemne zahĺbený plytký objekt s tmavohnedou výplňou pravidelného kruhového pôdorysu (pr. 0,25 m). Steny sa smerom ku dnu pozvolna znižujú a prechádzajú do plytkého dna v max. híbke 0,045 m od zachytenia. Profil objektu je v tvare písmena „U“. Objavený bol pri vyberaní juhozápadného okraja obj. 2.

Rozmery: dí. 0,25; š. 0,25; hí. 0,045 m.

Nálezy: bez nálezov.

Interpretácia: kolová jama; súčast' pôdorysu stavby domu.

\section{Objekt 3 (obr. 6: 1, 2)}

Do žltohnedého podložia jemne zahĺbený objekt $\mathrm{s}$ tmavohnedou výplňou takmer pravidelného kruhového pôdorysu (pr. 0,34 m). Steny sa smerom ku dnu pozvolna znižujú a prechádzajú plynule do plytkého dna v max. híbke 0,05 m od zachytenia. Objekt bol odkrytý najprv na polovicu (južná čast') a po dokumentácii bol vybraný celý až po podložie. Profil je v tvare písmena " $\mathrm{U}^{\prime \prime}$.

Rozmery: dí. 0,34; š. 0,35; hí. 0,05 m.

Nálezy: 41 ks črepov (z tohto 9 typických), min. 5 ks mazanice (z okolia objektu sa pri začistení podarilo vyzdvihnút aj kus úzkeho andezitového kameňa).

Interpretácia: kolová jama; súčast' pôdorysu stavby domu.

Objekt 4 (obr. 6: 3, 4)

Do žltohnedého podložia zahĺbený objekt s tmavohnedou výplňou nepravidelného kruhového až oválneho pôdorysu (pr. 0,35-0,38 m). Najprv bola odkrytá polovica (južná čast') a po dokumentácii bol vybraný celý až po podložie. Steny objektu sa na východnej strane smerom na dno v max. hlbke 0,3 m pozvolna znižujú. Na západnej strane je dno nepravidelné a značne zvýšené. Nachádza sa tu prehĺbenie (híbka približne 0,15 m), v ktorom bola výrazná koncentrácia štrkových kameňov.

Rozmery: dí. 0,35; š. 0,38; hí. 0,30 m.

Nálezy: 11 ks črepov (z okolia objektu sa pri začistení podarilo vyzdvihnút aj 1 ks úzkeho andezitového kameňa).

Interpretácia: kolová jama; súčast̉ pôdorysu stavby domu. Prehĺbenie v jame mohlo slúžit ako opatrenie na spevnenie ukotvenia kolu lomovým kameňom. 


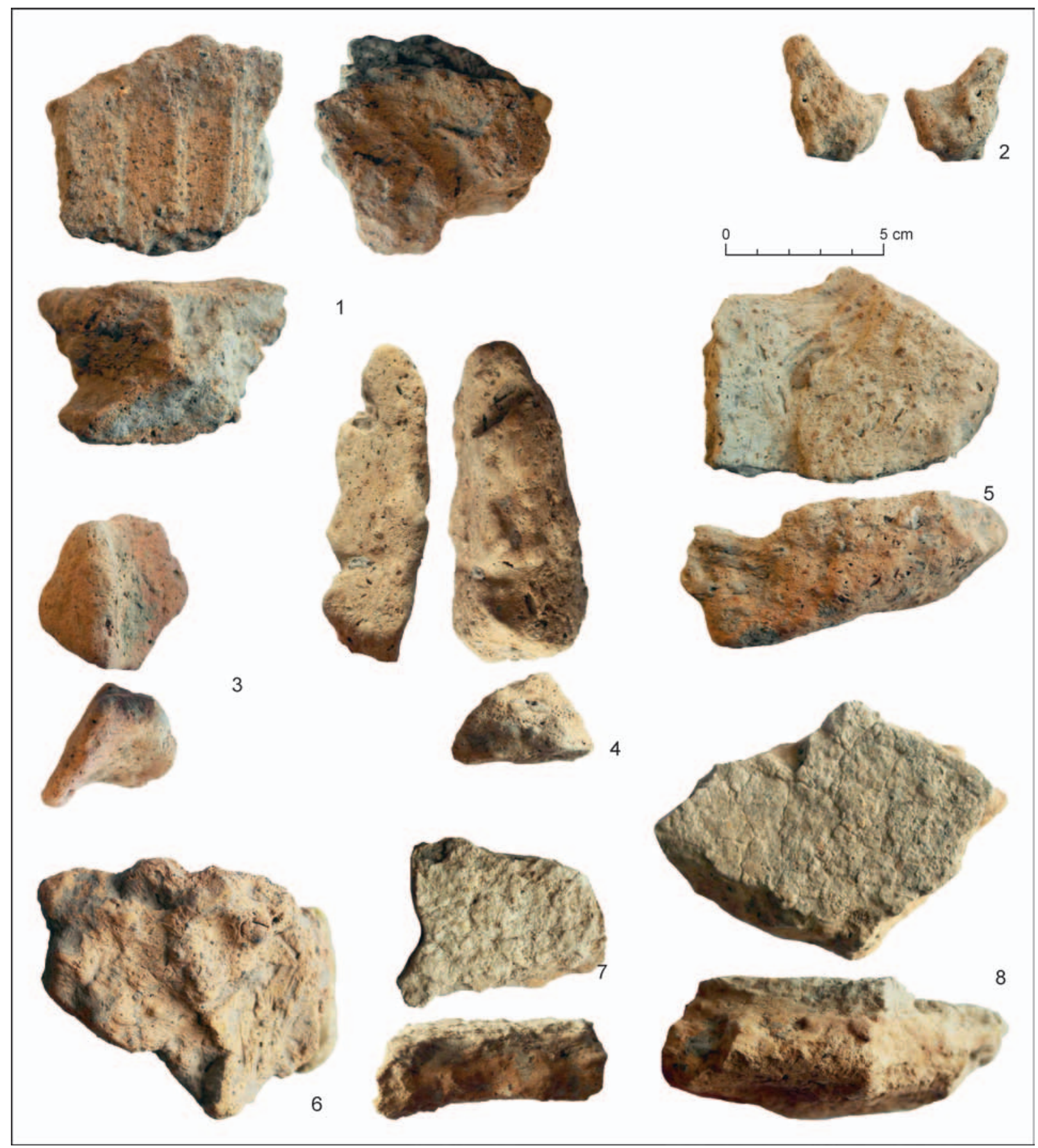

Obr. 7. Detva, Lúčna štvrt', parc. 7381/27. Mazanica s konštrukčnými prvkami.

\section{NÁLEZOVÝ SÚBOR}

Z archeologického výskumu parc. 7381/27, k. ú. Detva, pochádzalo početné množstvo hnutelných nálezov. Vieme ich rozdelit na keramické zlomky (259ks), kamenné artefakty (štiepaná industria, závažie, brúsik, podložka), mazanicu (desiatky kusov), andezitové kamene (15 ks).

Z plochy výskumu boli odobrané aj dve 51 vzorky hliny na archeobotanickú analýzu (z výplne obj. 2, z vrstvy V2) a ad-block bola vybraná deštruovaná piecka. Ich analýza v archeobotanickom laboratóriu Katedry archeológie UKF v Nitre však nevykázala žiadne zvyšky pestovaných druhov. Vo vzorkách sa vyskytli plano rastúce druhy, a to zuholnatené semená mrlíka bieleho (Chenopodium album L.) a bazy 
chabzdovej (Sambucus ebulus L.). Zároveň sa objavili aj zvyšky zuhol'nateného dreva (Acer sp.), ktoré sa nachádzali aj v podobe odtlačkov na dvoch kusoch mazanice.

\section{Mazanica}

Presný počet úlomkov mazanice nie je možné stanovit. Prevažne išlo o desiatky drobných kusov (max. vel'kost’ $2 \times 1 \mathrm{~cm}$ ) z výplne obj. 2, ktoré pochádzali pravdepodobne z výmazu kupoly piecky. Viaceré vykazovali prepálenie a nebolo možné presné určenie stôp po konštrukcii, resp. boli vel'mi nejasné kvôli malým rozmerom mazanice a jej značnej fragmentárnosti. Ďalších 32 väčších kusov mazanice (prevažne zo začistovania plochy v okolí objektov a 9 ks z výplne obj. 2) obsahovali stopy konštrukčných prvkov. Vzorky pochádzali s vel'kou pravdepodobnostou zo stavby, v ktorej interiéri sa piecka nachádzala. Reprezentatívny súbor (obr. 7) bol analyzovaný podla metodológie J. Ďuriša (2018).

Mazanica celkovo vykazovala prevažne stredne kompaktný habitus a bola materiálovo jednoliata, teda nemala výraznú organickú prímes. Materiál sa drvil a drobil len ojedinele (výnimku predstavovala ad-block vybraná čast’ piecky). Anorganické zrnká, resp. zložka (úlomky hornín) sa na mazanici nachádzala ojedinele vo vel'kosti 2-3 mm. Z hladiska farebnosti mazanica vykazovala škálu od bledosivo žltej až po stredne tehlovočerveno oranžovú.

Charakter konštrukčných prvkov na reprezentatívnom súbore mazanice bol nasledovný. Vzorky reprezentovali hlinený výmaz steny, hlinený výmaz s povrchovým omazom a plošný povrchový omaz. Hlinený výmaz plnil izolačný i ochranný charakter. Konštrukčná podoba ukázala jednoduchú vertikálnu líniu gulatiny i konštrukčné previazanie nosnej a podpornej gulatiny (vrátane kríženia s prútovinou), ktorá slúžila na lepšie spevnenie stien, resp. zabezpečenie ich stability. Ojedinele bolo možné zaznamenat horizontálnu paralelnost̉ medzi prútovinou/tyčovinou, resp. horizontálne pletenie medzi prútovinou/prútovinou. Taktiež sporadicky sa vyskytla horizontálna, resp. vertikálna paralelnost̉ medzi štiepaným drevom/štiepaným drevom. Na siedmich kusoch sa nachádzal jednostranný vyhladený rovný plošný povrchový omaz, pravdepodobne z exteriéru obvodovej steny. Ďalšie konštrukčné prvky na nich neboli zaznamenané.

\section{Keramika}

Napriek majoritnému podielu nevýraznej typovo-chronologicky insignifikantnej keramickej skladby sídliskového charakteru sa $\mathrm{v}$ súbore nachádzajú aj chronologicky výrazné prvky (55 typických črepov).

Amfory a amforovité vázy sú zastúpené fragmentom vel'kej svetlohnedej nádoby plynulej profilácie so zvýšeným kuželovitým hrdlom (obr. 8: 1), ktoré sa smerom von lievikovite roztvára. Má vzdialené príbuzné formy v lužickom prostredí stupňov HaA1-HaA2, no tie majú rovnejšie hrdlo. Nádoba pôsobí svojím výrazným lievikovite roztvoreným ústím archaizujúco. Presnejšie analógie vysledoval $P$. Śalkovský $(2001,45)$ v kyjatickom prostredí - Sajószentpéter, Szajla, Harsány a pod. (Kemenczei 1984, tab. 82: 20; 88: 12; 93: 3). Analogické nádoby v regióne nachádzame početne na blízkom hradisku Detva-Kalamárka (Šalkovský 2001, obr. 5: 3), kde predstavujú jeden z najzastúpenejších tvarov.

Fragment (obr. 9: 7) zdobený neupraveným vertikálnym zdrsnením, ktoré mohlo mat’ aj funkčný charakter, je dôležitý práve úpravou povrchu nakol'ko táto úprava je bežná v mladšej a neskorej dobe bronzovej. Podobné fragmenty pochádzajú napr. z obj. 1/60 (Studeníková/Paulík 1983, tab. III: 12) alebo 10/60 (Studeníková/Paulík 1983, tab. VI: 7) z lokality Pobedim. Na danom fragmente je možné pozorovat aj reparačný otvor.

Fragment doširoka roztvoreného lievikovitého ústia nenaznačuje celú tektoniku nádoby, ale môže pochádzat’ z členenej amforky (obr. 9: 5). Tie sú charakteristické pre mladolužické obdobie a pochádzajú napr. z Pobedimu z obj. 11/61 (Studeníková/Paulík 1983, tab. XIII: 1). Z tohto objektu pochádza aj další fragment (Studeníková/Paulík 1983, tab. XIII: 3), ktorý je zdobený klasickou plytkou jamkou (Studeníková/Paulík 1983, 110). Podobné ústia sú v Pobedime bežné. Vyskytli sa napr. aj v obj. 4/68 (Studeníková/Paulík 1983, tab. XXV: 1). Fragment zdobeného tela s takouto jamkou bol nájdený aj v Detve (obr. 8: 8) a bol navyše tuhovaný. Ide o bežnú výzdobu v lužickom prostredí mladšej a neskorej doby bronzovej.

Ďalší fragment nie je dostatočne zachovaný, aby bolo presne možné určit', z akej nádoby pochádza, ale podla vel'kosti, spôsobu vyhotovenia a naznačenej tektoniky môže íst' o jemne profilovanú 


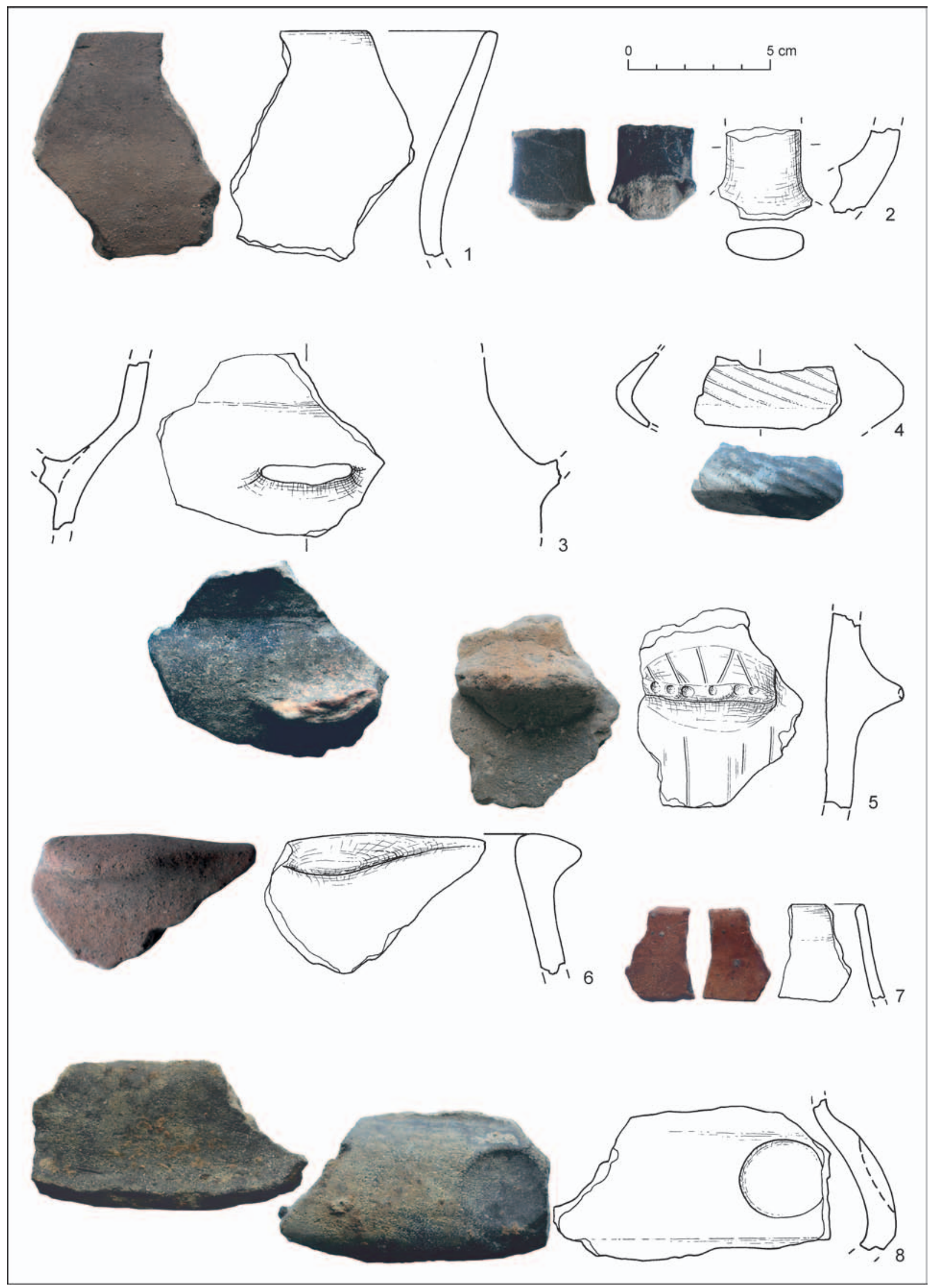

Obr. 8. Detva, Lúčna štvrt', parc. 7381/27. Výber tenkostennej a zdobenej keramiky. 

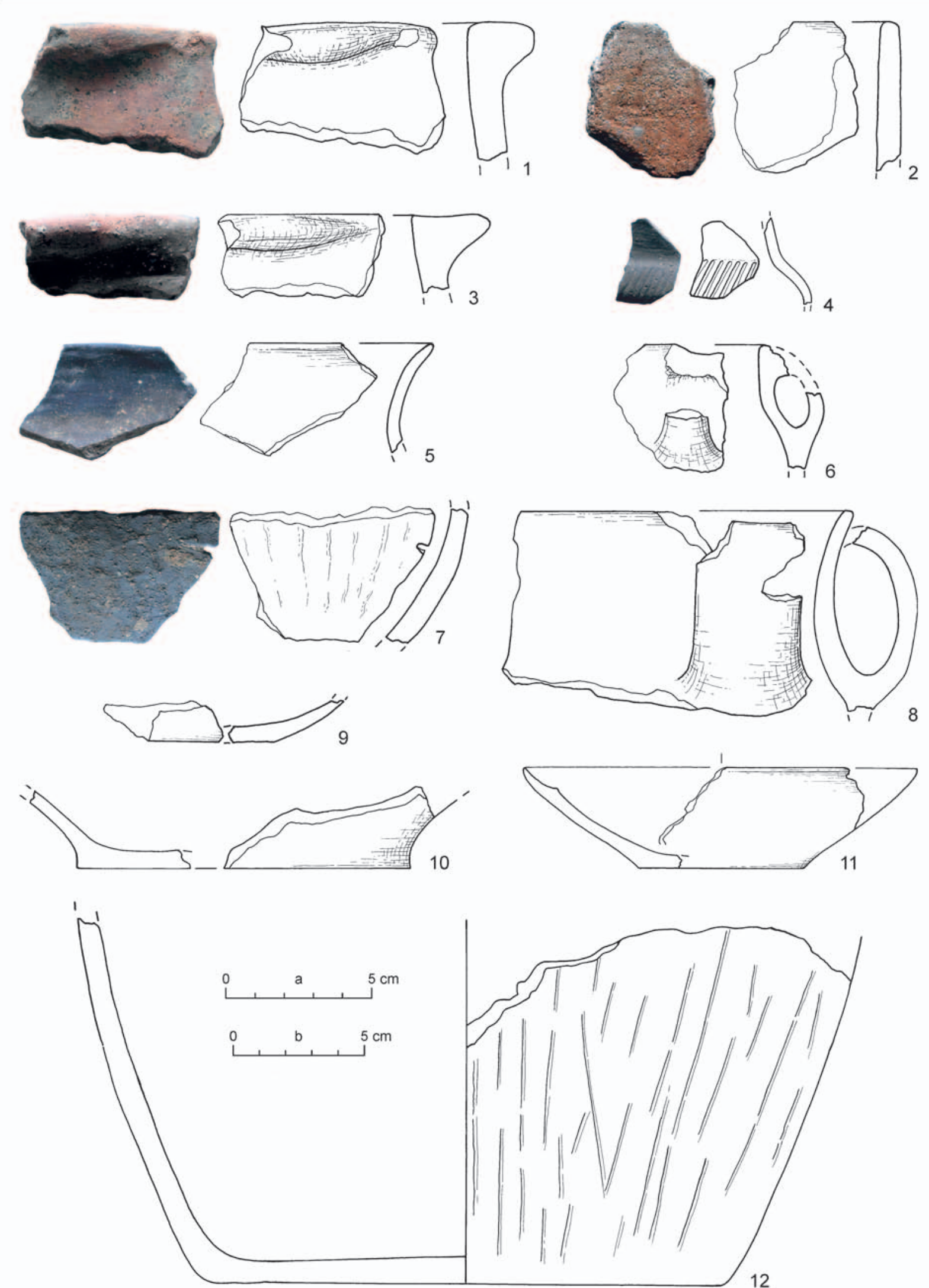

Obr. 9. Detva, Lúčna štvrt’, parc. 7381/27. Výber zdobenej keramiky a keramiky s funkčnými aplikáciami. Mierka: $\mathrm{a}-1-7,9 ; \mathrm{b}-8,10-12$. 


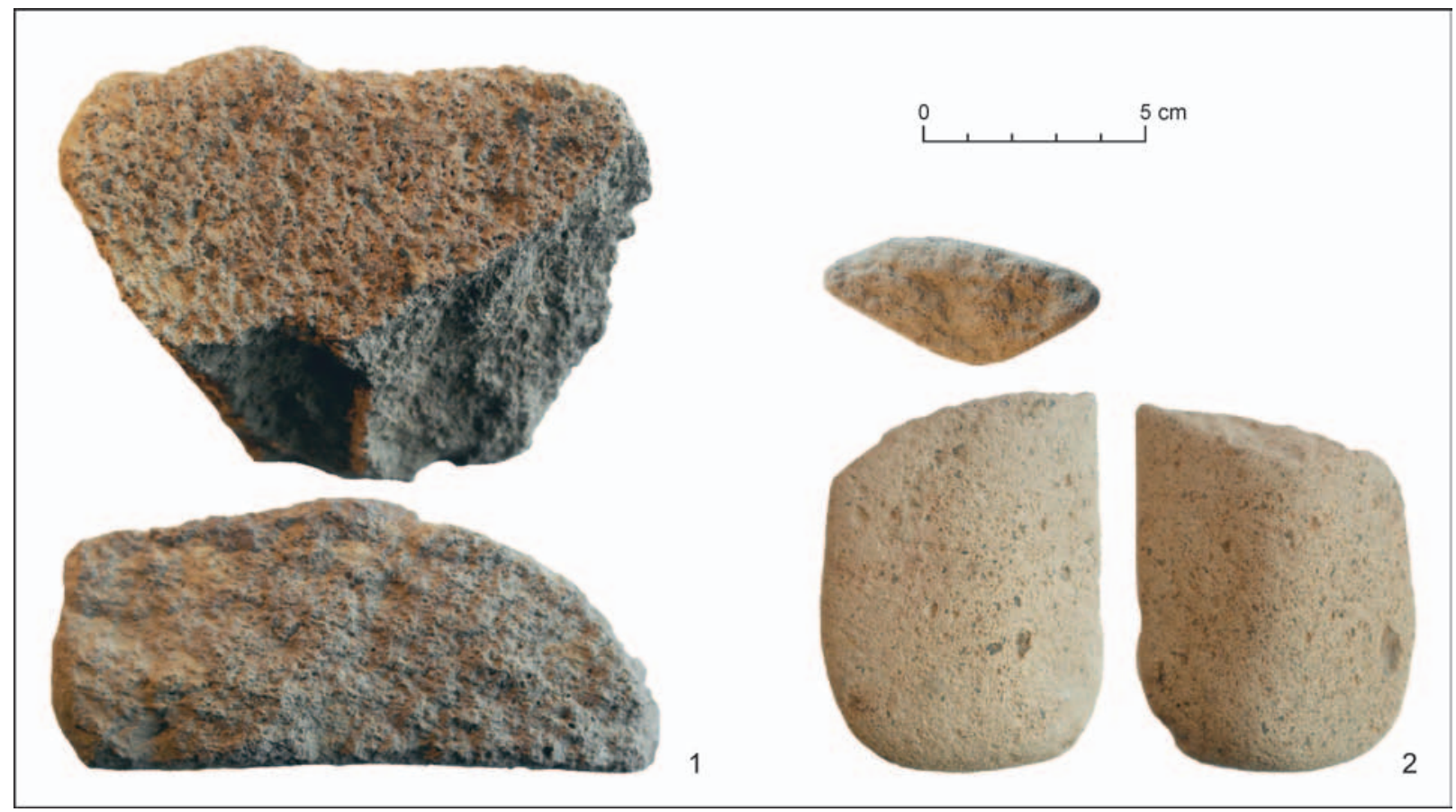

Obr. 10. Detva, Lúčna štvrt', parc. 7381/27. Nálezy z obj. 2.1 - kamenná podložka; 2 - brúsny kameň.

tenkostennú šálku, džbánok alebo amforku (obr. 9: 4). Nádoba je už značne horizontálna, sploštená a nízka, čo svedčí o mladšom chronologickom zaradení. Je zdobená hustým diagonálnym žliabkovaním. Blízke analógie môžeme hladat napr. vo Zvolene na pohrebisku Balkán v hrobe 24/54 (Bátora 1979, obr. 10: 7). Tento keramický tvar má v súbore aj dalšie zastúpenie, a to fragmentom vydutia (obr. 8: 4), aj ked' v inom vyhotovení. Je zdobený diagonálnym hranením, resp. facetovaním a ukazuje na juhovýchodný vplyv na toto územie v mladšom úseku popolnicových polí. Podobná výzdoba je opätovne badatelná v hrobe 27/54 na pohrebisku Zvolen-Balkán (Bátora 1979, obr. 10: 5), kde skupina šálok predstavuje horizont HaA. V horizontálnom sploštenom vyhotovení ide pravdepodobne dokonca o mladší materiál. Početné zastúpenie majú aj na hradisku Detva-Kalamárka (Šalkovský 2001, obr. 7: 4-7). Sú častým prvkom v stupňoch HaA až HaB, napr. v Diviakoch nad Nitricou - hroby 21 a 29 (Veliačik 1991, obr. 11: 13) alebo d’alšie exempláre z pohrebiska Zvolen-Balkán - hroby 69/54 a 131/54 (Bátora 1979, obr. 10: 7, 10, 11).

V období popolnicových polí je rozšíreným tvarom aj hrniec s dvomi pásikovými uchami na rozhraní hrdla a tela, ktoré končia tesne pod ústím nádoby (obr. 9: 8). Podobné nálezy pochádzajú z regiónu Hontu z Medovariec z hrobu 2/75 (Bátora 1979, obr. 8: 8) a zo Zvolena-Balkánu z hrobov 13/54 a 122/54 (Bátora 1979; obr. 9: 11, 14). Hrdlo je valcovite prehnuté a okraj mierne vytiahnutý von. Na Morave je výskyt takýchto hrncov velmi včasný. Sú známe už v neskoršej fáze vývoja mohylovej kultúry a vyskytujú sa aj v starolužickom stupni. Nálezový horizont tejto skupiny v regióne ale udáva pohrebisko Zvolen-Balkán, kde sa tieto hrnce vyskytujú spolu so šálkami s uchom vybiehajúcim nad okraj. Datujú ho do prelomu stupňov HaA a HaB (Bátora 1979, 64).

V zaujímavom vyhotovení je zastúpený jazykovitý výčnelok (obr. 8: 5) na fragmente tela pravdepodobne hrncovitej nádoby (možno súdkovitý hrniec). Špička ,jazyka“ je zdobená vhíbenými jamkami a z jednej strany výčnelku aj rytými líniami. Jeho najbližšia analógia pochádza z hradiska Detva-Kalamárka. Absentuje na nej ale rytá výzdoba (Šalkovský 2001, obr. 8: 6). Súdkovité hrnce aj s lalokovými jazykovitými výčnelkami na ústí nádoby (obr. 9: 1,3) sú v súbore preukázatelne zastúpené. Tieto tvary sú rovnako vlastné lužickým aj juhovýchodným popolnicovým poliam, pričom je zistený ich všeobecný vývojový trend od vyšších ovoidných-esovitých $\mathrm{k}$ vakovitým-súdkovitým. Dokladajú osídlenie lokality v mladších fázach oboch kultúr v HaA až HaB (Šalkovský 2001, 47, tu príklady analógií z oboch kultúrnych prostredí).

Jemne profilovaný súdkovitý hrniec s pásikovým uškom, vychádzajúcim priamo z vtiahnutého hrdla (obr. 9: 6), patrí k bežnej výbave lužicko-kyjatického prostredia v HaA2 až HaB, napr. Diviaky nad 


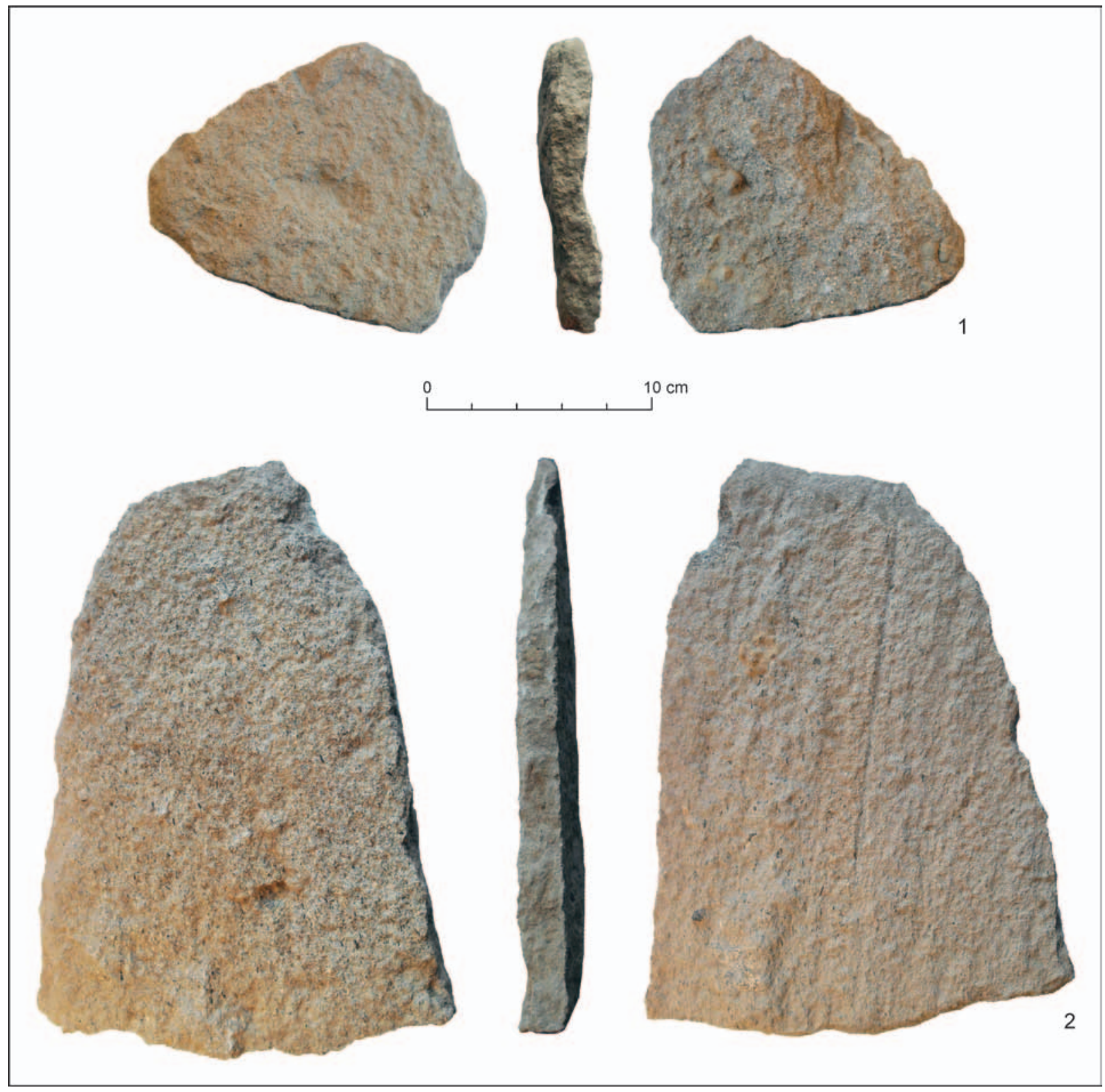

Obr. 11. Detva, Lúčna štvrt', parc. 7381/27. Ploché úzke andezitové kamene z kultúrnej vrstvy v okolí obj. 3 a obj. 4.

Nitricou - hrob 68, Radzovce; Sajózentpéter-Vízmű; Háj - hroby 57 a 71 (Šalkovský 2001, 47). Totožné exempláre pochádzajú aj z Detvy-Kalamárky (Šalkovský 2001, obr. 9: 1; 4: 5).

\section{Kamenné podložky, nástroje a industria}

Kamenné podložky sa na archeologických lokalitách všeobecne objavujú len vo fragmentárnom stave. Priamo z výplne obj. 2 (vrstva V2) pochádza fragment okrajovej časti podložky (obr. 10: 1). Jej vel'kost’ je $11 \times 9 \mathrm{~cm}$ s max. hrúbkou $4 \mathrm{~cm}$. Pracovná plocha má povrch hladený, avšak bez výraznejších stôp po pracovnej činnosti. Spodná čast̉ predmetu je pomerne rovná a smerom k okraju sa steny podložky zaoblujú. V praveku mali kamenné podložky široké využitie, napr. pri príprave jedál na drvenie obilia, roztieranie minerálnych farbív, grafitu atd'.

Pri začistovaní v okolí obj. 3 aj 4 boli objavené dve pomerne úzke, ale rozmerovo väčšie nepravidelné fragmenty plochých andezitových kameňov (obr. 11). Zrejme pôvodne nepochádzali z jedného kusu. 


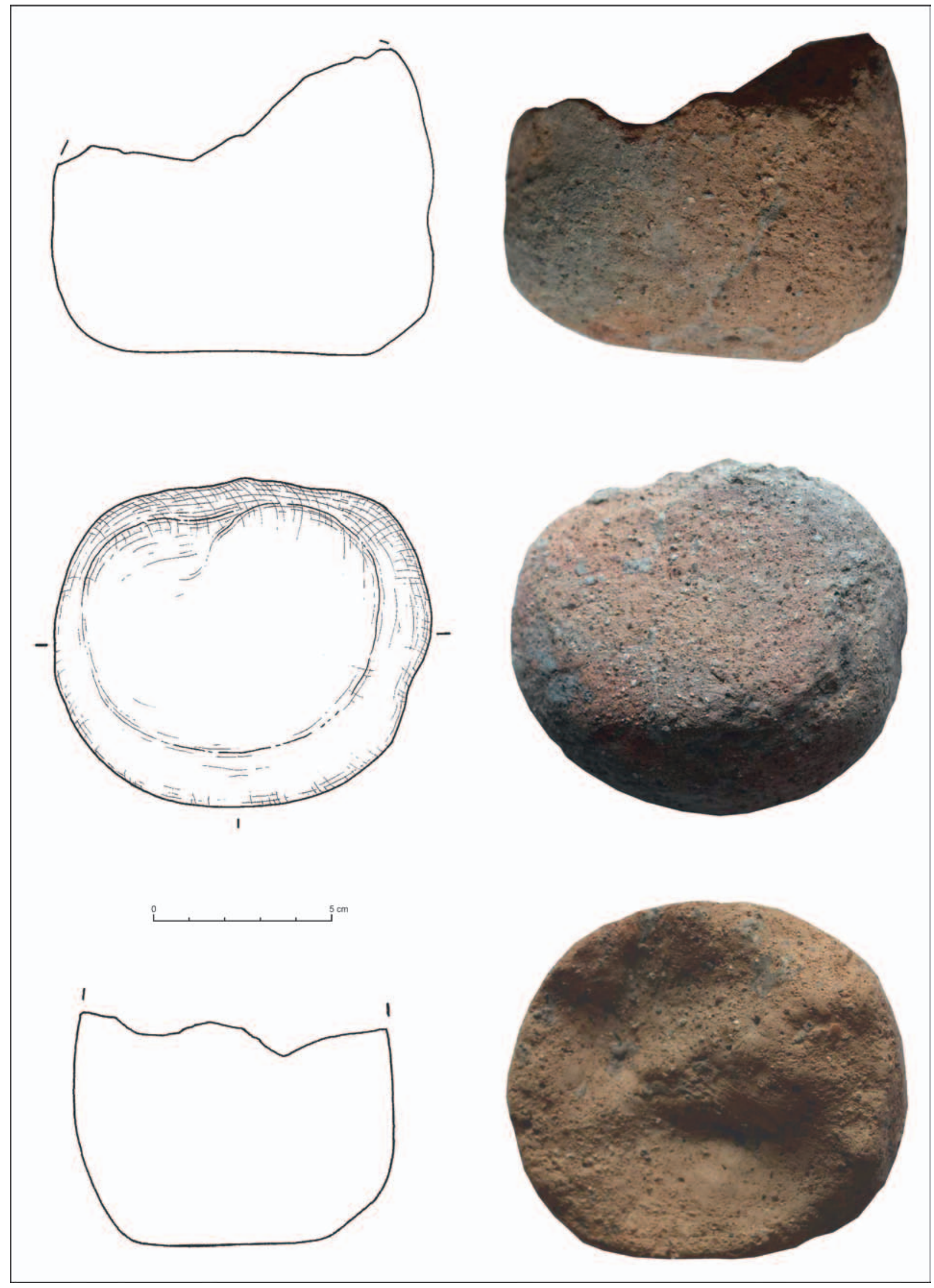

Obr. 12. Detva, Lúčna štvrt', parc. 7381/27. Nález fragmentu kamenného závažia z obj. 2. 
Ich vel'kost' bola 12 × $12 \mathrm{~cm}$ a 17 × $25 \mathrm{~cm}$, hrúbka dosahovala 1,5-2 cm. Na nálezoch neboli viditelné žiadne stopy po pracovnej činnosti a ani jedna strana nedisponovala výlučne hladeným povrchom. Zrejme nešlo o pracovné nástroje, ale mohli byt súčastou izolácie, prípadne tvorili podklad pôvodnej kamennej podmurovky v pôdoryse stavby. Paralely takéhoto konštrukčného riešenia je možné badat' napr. v prípade domu 3 patriacej kyjatickej kultúre na lokalite Radzovce (Ďuriš 2018, 73-75, obr. 8).

Na hospodárske, resp. výrobné aktivity ukazuje fragment závažia tkáčskeho stavu (obr. 12) objavený v severnej polovici obj. 2. Pôvodne išlo o masívne závažie kuželovitého tvaru s okrúhlym dnom. Takéto tvary sú v mladšej až neskorej dobe bronzovej pomerne častým sídliskovým nálezom. Na základe zachovanej časti nie je možné postrehnút značku vo vrchnej časti predmetu. Rozmery závažia: pr. dna 10 cm, výška fragmentu $9 \mathrm{~cm}$.

Ďalší pracovný nástroj je kamenný brúsik (obr. 10: 2). Bol objavený v obj. 2 a jeho zlomok mal vel'kost' 7,5 x 5,5 cm a max. hrúbku $2,5 \mathrm{~cm}$. Vyrobený bol z tvrdého pieskovca (?). Brúsiky mali rôznorodé využitie, často slúžili na ostrenie pracovných nástrojov pri polnohospodárskej činnosti obyvatelov, ale mohli sa nimi ostrił aj nože a pod.

Z výskumu pochádzal aj jeden kus kamennej štiepanej industrie. Objavený bol taktiež vo výplni obj. 2. Ide o neopracovanú čepel' (druhotnú z hrany jadra) s max. šírkou $1,4 \mathrm{~cm}$ a výškou $5,8 \mathrm{~cm}$ (obr. 13). Vyrobený je z miestneho limnosilicitu, ktorého najbližšie ložiská sú v Žiarskej kotline.

\section{VYHODNOTENIE \\ A DATOVANIE OSÍDLENIA}

Minulé archeologické výskumy v katastri mesta Detva i v bližšom okolí poukazujú na bohaté polykultúrne osídlenie územia (Beljak Pažinová 2018). Prvé stopy človeka evidujeme zo záveru staršej doby kamennej. Mladopaleolitické osídlenie bolo identifikované v okolí kóty 468, Voliarky na pravom brehu Slatiny, kde sa našlo škrabadlo a silicitové úštepy (Bárta 1978, 28). Hoci opomenút nemožno ani mladšiu, prípadne neskorú dobu kamennú, ked’ hlavne v období ludanickej skupiny, resp. badenskej kultúry v oblasti vznikali osady (Beljak/Beljak Pažinová 2017; Beljak Pažinová 2014; Šalkovský 2018, 42). Najvýraznejšie stopy zanechalo až osídlenie z mladšej a neskorej doby bronzovej. Vo východnej časti Zvolenskej kotliny sa z tohto obdobia objavujú nálezy z viacerých polôh (Detva-Krnô, Melichova skala, vrch Detva), pričom k najznámejším sídliskám na Podpolaní patrí skalná plošina Kalamárka (Šalkovský 1994; 2001), ktorá bola opevnená v závere neskorej doby bronzovej, a jej predpolie, Chrapková. Na lúkach, juhovýchodne a južne od Kalamárky, vzniklo v neskorej dobe bronzovej aj otvorené sídlisko a na jeho okraji žiarové pohrebisko kyjatickej kultúry (Mosný 1995). Výšinné hradisko Kalamárka (800-808 m n. m.), ktoré je od centra Detvy vzdialené približne $5 \mathrm{~km}$, ležalo na dial'kovej komunikácii vedúcej údolím Kriváňa z juhovýchodného na Stredné Slovensko, pričom taž̌ilo z dial'kového obchodu a strážilo horský priechod i bezpečnost dial'kovej cesty. Ide zároveň o polykultúrnu lokalitu s potvrdeným osídlením aj v dobe halštatskej, laténskej, rímskej, období stahovania národov až do včasného stredoveku (Šalkovský 2002; 2018, 43-51).

Žiadnym prekvapením teda nebolo, ked' bola v centre mesta Detva v časti Lúčna štvrt’ identifikovaná d’alšia osada zo záveru doby bronzovej, ktorá zároveň mohla slúžit ako hospodárske zázemie Kalamárky. Hoci v Lúčnej štvrti už archeologický dozor na niekol’kých parcelách realizovaný bol (informácia z Krajského pamiatkového úradu v Banskej Bystrici) a z polohy bol už v minulosti zdoku- 
mentovaný zberový materiál (Hrončiak 2018), až počas sledovania terénnych úprav v apríli 2016 sa na sledovanej parc. 7381/27 podarilo identifikovat prvé nehnutel'né archeologické objekty.

V juhozápadnej časti parcely na ploche s vel'kostou $10 \mathrm{~m}^{2}$ boli zaznamenané štyri pomerne pravidelné kruhové kolové jamy s priemerom okolo $0,3-0,35 \mathrm{~m}$ a ešte zachovanou híbkou medzi $0,05-0,3 \mathrm{~m}$. Do týchto jám bol pôvodne zapustený drevený stĺp (kôl), ktorý tvoril súčast̉ kolovej konštrukcie stavby. Jednotlivé kolové jamy boli pravidelne rozložené a ich stredy boli od seba v severo-južnom i východo-západnom smere vzdialené presne $2 \mathrm{~m}$. Po vyhnití dreva sa jamy vyplnili hlinou a v ideálnych prípadoch sa aj do týchto jám dostala čast̉ materiálnej kultúry, ktorú sme počas výskumu vyzdvihli. Na základe dispozičného rozloženia identifikovaných kolových jám je možné predpokladat’ d’alšie dve v rovnakej vzdialenosti východným smerom. Nakol'ko však neboli hlboko zapustené, ich stopy sú velmi nepatrné (jemný od podložia odlišný farebný flak) a pri obrábaní svahu a terajšej skrývke ornice došlo $\mathrm{k}$ ich deštrukcii.

Podla rozmiestnenia kolových jám (obr. 2) vieme rekonštruovat pôdorys sídliskového objektu, ktorý sa tu pôvodne nachádzal. Išlo zrejme o nadzemnú jednopriestorovú obytnú stavbu kvadratického pôdorysu, v ktorej interiéri sa nachádzalo tepelné zariadenie. Piecka situovaná pri južnej stene stavby v blízkosti kolovej jamy bola v deštruovanom stave. Jej objavené časti pozostávali zo zhoreného výmazu deštruovaných stien, prípadne kupoly. Tvar mala kruhový až jemne oválny (pr. asi 1,5 m) a siahala do híbky približne $0,5 \mathrm{~m}$. Jej funkcia bola pravdepodobne vykurovacia. Vo výplni objektu sa nachádzal značný počet črepov, pracovné nástroje (čepel', brúsny kameň, podložka, závažie) i andezitové kamene. Tie mohli slúžit ako izolácia vykurovacieho zariadenia. Ďalšie dve úzke ploché andezitové kamene, objavené vo vrstve v blízkosti kolových jám pri severnej stene stavby, mohli pôvodne tvorit podklad pôdorysu stavby v podobe určitej podmurovky. Analogické situácie boli zaznamenané na d’alších lokalitách mladšej a neskorej doby bronzovej (Ďuriš 2018, obr. 8; Furmánek 1990, 24-26; Furmánek et al. 2015, 259, 264).

Vzájomné časové prepojenie stavby domu a vykurovacieho zariadenia dokazujú dispozičné väzby, ako aj materiálna kultúra. Na základe rozboru keramického materiálu, v ktorom dominujú rôzne misky, hrnce a amfory aj s kvalitnou čiernou leštenou úpravou povrchu (vrátane šikmého i zvislého žliabkovania), je možné lokalitu datovat’ do obdobia konca mladších až neskorých popolnicových polí stupňov HaA2-HaB. Jej geografická poloha na periférii lužickej a kyjatickej kultúry sa odráža aj v keramickom inventári, kde badat prvky z oboch kultúrnych okruhov. Aj ked' niektoré archaizujúce prvky prežívajúce z mladších popolnicových polí poukazujú na datovanie do staršieho stupňa spomínaného intervalu, práve intenzita elementov kyjatickej kultúry na keramike a tendencia nádob k horizontálnemu sploštenému vyhotoveniu nabáda na datovanie lokality do neskorej doby bronzovej.

O bežnom živote ludí na tomto sídlisku svedčia okrem keramiky aj doklady výrobného charakteru. Je to napr. tkáčske závažie, ktoré dokladá textilnú produkciu, dalej fragment osličky, brúsneho kameňa, ktorý by sprostredkovane mohol svedčit o polnohospodárstve. Nález zrnotierky zas vypovedá o príprave potravy obyvatelov.

O environmente osady vel’a informácií nemáme. Na základe identifikovaných planorastúcich druhov vieme konštatovat', že osada sa nevymyká z rámca iných dobových osád z územia Slovenska (Hajnalová 2012, 70-92). Polnou burinou je mrlík, ktorý sa do osady dostal asi spolu s pozbieranou úrodou obilnín, strukovín prípadne technických rastlín. Naopak, zbieraným plodom bola baza. Ide o ker, resp. menší strom, ktorý rástol na okrajoch polí, medzí, lesov, ako aj na zarastajúcich pasienkoch a lúkach.

\section{DISKUSIA}

Preskúmaná plocha a identifikovaná stavba domu je len nepatrnou častou pôvodnej osady, ktorá sa tu v neskorej dobe bronzovej mohla nachádzat'. Ďalšie sídliskové objekty vyplnené popolovitou vrstvou hliny sa podarilo identifikovat aj západným smerom vyššie na svahu, a to počas d’alšieho archeologického výskumu v máji-júni 2016 na parc. 7381/29 (Kvietok/Hrončiak 2016). Pôdorys domu s rozmermi 5 × 8 m, ako aj d’alšie objekty boli zaznamenané na parc. 7381/28 a 7328/20 v marci-apríli 2017 (Kvietok/ Kvietková 2017). Tieto výskumy realizovalo Stredoslovenské múzeum v Banskej Bystrici, resp. súkromná archeologická spoločnost̉ Midland Adventure, s. r. o. pod vedením archeológov M. Kvietka, V. Kvietkovej a R. Hrončiaka. Výsledky z nich budú publikované samostatne. 


\section{ZÁVER}

Objavenie pravekej lokality uprostred Detvy zo záveru doby bronzovej poukazuje na vel'ký význam jej územia začiatkom posledného tisícročia pred Kristom a je svedectvom o intenzívnom osídlení i nížinných na polnohospodárstvo využívaných polôh v oblasti Polany. Toto novoobjavené osídlenie korešponduje so známym pravekým hradiskom Kalamárka, vzdialeným od mesta Detva severným smerom približne $5 \mathrm{~km}$. Strategická výšinná lokalita bola prvýkrát osídlená v neskorej dobe bronzovej práve lužickou i kyjatickou kultúrou. V kontexte nálezovej situácie mohlo íst’ v prípade náleziska v časti Lúčna štvrt’ v Detve o okrajový výrobný areál nížinného sídliska, ktoré bolo s týmto hradiskom súveké a nepochybne bolo v jeho zázemí.

Materiál z otvorených sídlisk z mladšej a neskorej doby bronzovej v regióne poznáme väčšinou len z povrchových zberov a prieskumov, preto je obzvlášt dôležité a unikátne, že sa priamo v Detve podarilo identifikovat tieto nehnutelné stopy minulého osídlenia. Objavená bola kvadratická stavba, dom so štyrmi jednoznačne zachytenými kolovými jamami a na základe pôdorysnej situácie predpokladanými d’alšími aspoň dvomi kolovými jamami, ktoré poukazujú na minimálny rozmer stavby $2 \times 4 \mathrm{~m}$. V jej interiéri sa nachádzalo tepelné zariadenie, piecka, ktorá mohla slúžit na vykurovanie, ale aj prípravu jedál. Výskyt andezitových kameňov v kultúrnej vrstve interiéru stavby vypovedá o konštrukčnom prvku slúžiacom na izoláciu.

Geografická poloha sídliska na periférii lužickej a kyjatickej kultúry sa odráža aj v keramickom inventári, kde badat prvky z oboch kultúrnych okruhov. Intenzita elementov kyjatickej kultúry na keramike a tendencia nádob k horizontálnemu sploštenému vyhotoveniu nabáda na datovanie lokality do neskorej doby bronzovej. Tvary identifikovaných nádob (rôzne misky, hrnce a amfory) a ich kvalita vyhotovenia vypovedajú o stolovej i bežnej domácej keramike, ktorú obyvatelia sídliska používali. Kamenné nástroje sú svedectvom polnohospodárskej činnosti i textilnej výroby.

Charakter objaveného sídliska svedčí o usadlom spôsobe života na miernom svahu v blízkosti vodných tokov a jej polnohospodárskom charaktere. Samotná praveká osada s d’alšími hospodárskymi i obytnými stavbami sa rozprestierala na rozsiahlej ploche južnejšie aj západnejšie od sledovanej parc. 7387/27, k. ú. Detva. Nakol'ko stavebná činnost’ v Lúčnej štvrti v Detve je len na začiatku a naplánované sú tu stavby d’alších rodinných domov, inžinierske siete i cestná komunikácia, je samozrejmé, že dalšie archeologické výskumy na lokalite prinesú početné nové nálezy hnutel’ného i nehnutelného charakteru, ktoré potvrdia a doplnia nami zistené informácie o sídlisku.

\section{LITERATÚRA}

Bátora 1979

Bárta 1978

Beljak/Beljak Pažinová 2017

Beljak Pažinová 2014

Beljak Pažinová 2018

Ďuriš 2018

Furmánek 1990

Furmánek et al. 2015

Hajnalová 2012

Hrončiak 2018

Kemenczei 1984

Kvietok/Hrončiak 2016
J. Bátora: Žiarové pohrebiská lužickej kultúry v oblasti Zvolena. Slovenská archeológia 17, 1979, 57-84.

J. Bárta: Archeologický prieskum Ipel'skej, Lučeneckej, Pliešovskej a Zvolenskej kotliny. AVANS 1977, 1978, 27-29.

J. Beljak/N. Beljak Pažinová: Najstaršie dejiny územia Klokoča. In: J. Golian/J. Výboštok a kol.: Obec Klokoč. História a súčasnost'. Klokoč 2017, 34-43.

N. Beljak Pažinová: Kultúrne a chronologické vzt’ahy Stredného Pohronia v neolite a eneolite. In: M. Popelka/R. Šmidtová (ed.): Neolitizace aneb setkání generací. Soubor příspěvků z konference 13.-14. března 2014 v Praze. Praha 2014, 219-242.

N. Beljak Pažinová: Osídlenie Zvolenskej kotliny v praveku. In: N. Beljak Pažinová/Z. Borzová (ed.): Stredné Slovensko v stredoveku. Vývoj osídlenia regiónu pred udelením mestských privilégií mestu Zvolen. Zvolen 2018, 6-33.

J. Ďuriš: Radzovce v období popolnicových polí. Nitra 2018.

V. Furmánek: Radzovce. Osada l’udu popolnicových polí. Bratislava 1990.

V. Furmánek et al.: Staré Slovensko 4. Doba bronzová. Nitra 2015.

M. Hajnalová. Archeobotanika doby bronzovej na Slovensku. Štúdie ku klíme, prírodnému prostrediu, pol'nohospodárstvu a paleoekonómii. Nitra 2012.

R. Hrončiak: Nález pravekých črepov v Detve. AVANS 2013, 2018, 69, 70.

T. Kemenczei: Die Spätbronzezeit Nordostungarns. Budapest 1984.

M. Kvietok/R. Hrončiak: Novostavba rodinného domu, Detva parc. 7381/29 v k. ú. Detva. Výskumná správa 2/2016. Dokumentácia Stredoslovenského múzea Banská Bystrica 2016. Banská Bystrica 2016. Nepublikované. 
Kvietok/Kvietková 2017

Mosný 1995

Studeníková/Paulík 1983

Šalkovský 1994

Šalkovský 2001

Šalkovský 2002

Šalkovský 2018

Veliačik 1991
M. Kvietok/V. Kvietková: „Rodinný dom“ v k. ú. Detva. Výskumná správa 3/2017. Dokumentácia Midland Adventure, s. r. o. Banská Bystrica 2017. Nepublikované. P. Mosný: Prieskum v okresoch Banská Bystrica a Zvolen. AVANS 1993, 1995, 99. E. Studeníková/J. Paulík: Osada z doby bronzovej v Pobedime. Bratislava 1983. P. Šalkovský: Hradisko v Detve. Materialia Archaeologica Slovaca Tomus 11. Nitra 1994.

P. Šalkovský: Výšinné hradisko v Detve - osídlenie v mladšej a neskorej dobe bronzovej. Slovenská archeológia 49, 2001, 39-58.

P. Šalkovský: Výšinné hradisko v Detve - protohistorické osídlenie. Slovenská archeológia 50, 2002, 96-126.

P. Šalkovský: Praveké a včasnohistorické osídlenie Detvy a okolia. In: A. Ostrihoňová (ed.): Detva. Monografia mesta. Detva 2018, 42-51.

L. Veliačik: Beitrag des Gräberfeldes in Diviaky nad Nitricou zur Chronologie der Denkmäler der Lausitzer Kultur in der Slowakei. Slovenská archeológia 39, 1991, 143-214.

\title{
The Settlement from the Late Bronze Age in Detva, Lúčna štvrt' (Meadow District) Site
}

\author{
Noémi Beljak Pažinová - Ladislav Chmelo
}

Summary

The Department of Archaeology of the Constantine the Philosopher University in Nitra carried out rescue excavation in Lúčna štvrt' (Meadow district) in the centre of Detva in mid April 2016, during construction of a detached house on building plot 7381/27.

Lúčna štvrt' is situated on the interface between the old historical part of the town and the new housing estate of Detva. The site is located on a slope falling south-eastwards to the Detviansky potok stream. The building plot was previously used as farm land - it was a meadow.

In the south-western part of the building plot, four regularly distributed pole pits with diameters of approx. $0.3-0.35 \mathrm{~m}$ and preserved depth of $0.05-0.3 \mathrm{~m}$ (feature $1,2 \mathrm{~A}, 3,4$ ) were discovered, together with one settlement feature with a distinct layer of burned earth and charcoals (destroyed heating device) - feature 2. The features were parts of a single-space above-ground residential structure with a quadratic groundplan whose interior contained the heating device (diameter of approx. $1.5 \mathrm{~m}$, sunk $0.5 \mathrm{~m}$ deep). A considerable number of sherds, working tools (blade, grinding stone, slab, weight) and andesite stones was found in the backfill of feature 2 . The stones could have been used as insulation of the heating device. Other two narrow andesite stones discovered in the layer near the pole pits near the northern wall of the structure could have been the original base of the structure's groundplan, maybe in form of a socle.

The archaeological research brought pottery (259 fragments), chipped stone industry (1 piece), lithic tools (weight, whetstone, and slab), daub (tens of exemplars), and andesite stones (15 pieces). Wild growing species Chenopodium album L. and Sambucus ebulus L. occurred in the obtained and analyzed samples of soil from the backfill of feature 2 . There were also remains of carbonized wood of Acer sp. which were found in form of imprints on two pieces of daub.

On the basis of analysis of the pottery material in which various bowls, pots and amphorae - also with high-quality black burnished surface finish (including oblique and vertical flutings) - prevail, the site can be dated to the end of the late or final Urnfield culture, stages $\mathrm{HaA} 2-\mathrm{HaB}$. Its geographical location on the periphery of the Lusatian and Kyjatice cultures is reflected also in the pottery inventory where we can observe elements from both cultural spheres. Although some archaizing elements surviving from the later Urnfield culture suggest dating to the older stage of the above mentioned interval, it is the intensity of elements of the Kyjatice culture in the pottery and the tendency of the vessels to horizontally flattened shape that suggests dating of the site to the Late Bronze Age.

Besides pottery, the everyday life of the people at the settlement is documented by evidence of production character. The evidence includes for instance a loom weight, which points to textile production, a fragment of a whetstone, which could indirectly confirm for instance farming. The find of a grinding slab might document preparation of food.

Wild growing species, particularly chenopod - which probably arrived at the settlement together with gathered crops - and elderberry growing on the edges of fields, balks or forests as well as overgrown pastureland and meadows, they all document the environment of the settlement. 
The searched area and the identified structure of the house are just a small part of the original prehistoric settlement which could have been situated there in the Late Bronze Age.

The discovery of the settlement in the centre of Detva points to the great importance of its territory in the beginning of the last millennium BC and is a testimony of the intense settlement also in the lowland sites of the Polana hills used for farming. This newly discovered settlement corresponds with the known prehistoric hillfort of Kalamárka situated approx. $5 \mathrm{~km}$ north of Detva. This strategically situated upland site was first settled in the Late Bronze Age by the Lusatian and Kyjatice cultures. Judging from the find context, the site in Lúčna štvrt’ (Meadow district) in Detva could have been a peripheral production area of a lowland site which was contemporary with the hillfort and was undoubtedly situated in its hinterland.

Fig. 1. Detva, Lúčna štvrt', building plot no. 7381/27. Location of investigation on basic topographic map 1 : 10000. Yellow colour indicates the plot with groundplan of a family house. Red colour indicates the area with find contexts.

Fig. 2. Detva, Lúčna štvrt', building plot no. 7381/27. Documentation of the course of investigation.

Fig. 3. Detva, Lúčna štvrt', building plot no. 7381/27. Identified archaeological features in the excavated area. 1, 2A, 3, 4pole pits (solid yellow line); 2 - heating device (solid red line); other assumed pole pits (dashed yellow line).

Fig. 4. Detva, Lúčna štvrt', building plot 7381/27. Documentation of the cultural layer (green colour) and the pole pit of feature 1 (dashed yellow line). Legend: $\mathrm{V}$ - dark black filling of the feature; dot-and-dash line - limit of the building plot.

Fig. 5. Detva, Lúčna štvrt', building plot 7381/27, feature 2. 1 - trimmed goundplan; 2 - southern profile; 3 - gradual extraction from the feature; 4 - after extraction of the southern half of the feature; 5 - documentation of the heating device (feature 2) and pole pit (feature 2A). Legend: V1 - solid bright red burned daub layer; V2 - dark grey-black filling of the feature; V3 - greyish to greay-white ash layer; V4 - grey-black compressed clay layer; a - JCB anchoring, damaged part of the feature; $b$ - pole pit (feature 2A); - pottery; $d$ - daub; e- andesite rocks; $f$ - limits of the feature after extraction down to the clay subsoil.

Fig. 6. Detva, Lúčna štvrt', building plot 7381/27. Documentation of pole pits. 1, 2 - feature 3; 3, 4 - feature 4 . Legend: $\mathrm{V}$ - dark brown filling of the feature.

Fig. 7. Detva, Lúčna štvrt’, building plot 7381/27. Daub with construction elements.

Fig. 8. Detva, Lúčna štvrt', building plot 7381/27. Selected thin-walled and decorated pottery.

Fig. 9. Detva, Lúčna štvrt', building plot 7381/27. Selected decorated pottery and pottery with functional applications. Scale: $a-1-7,9 ; b-8,10-12$.

Fig. 10. Detva, Lúčna štvrt', building plot 7381/27. Finds from feature 2. 1 - grinding slab, 2 - grinding stone.

Fig. 11. Detva, Lúčna štvrt, building plot 7381/27. Flat and narrow andesite rocks from the cultural layer near features 3 and 4 .

Fig. 12. Detva, Lúčna štvrt', building plot 7381/27. Find of a fragment of a stone weight from feature 2.

Fig. 13. Detva, Lúčna štvrt', building plot 7381/27. Find of chipped stone industry from feature 2.

Translated by Mgr. Viera Tejbusová

doc. PhDr. Noémi Beljak Pažinová, PhD.

Katedra archeológie

Univerzita Konštantína Filozofa v Nitre

Tr. A. Hlinku 1

SK - 94974 Nitra

nbpazinova@ukf.sk
Mgr. Ladislav Chmelo, PhD.

Irish Archaeological Consultancy

Kilcoole

Co. Wicklow

Ireland A63 KT32

1chmelo@gmail.com 